\title{
Determinants of Foreign Direct Investment in Saudi Arabia: A Review
}

\author{
Haga Elimam ${ }^{1}$ \\ ${ }^{1}$ King Abdulaziz University, KSA \\ Correspondence: Haga Elimam, King Abdulaziz University, KSA. E-mail: helimam@outlook.com
}

Received: April 24, 2017

Accepted: June 5, 2017

Online Published: June 25, 2017

doi:10.5539/ijef.v9n7p222

URL: https://doi.org/10.5539/ijef.v9n7p222

\begin{abstract}
Foreign direct investment is identified as the major tool for the movement of international capital. Thus, the study has employed a review research to examine the determinants of foreign direct investment in Saudi Arabia. The results are significant as they have contributed towards determinants of foreign direct investment by comparing with previous studies. The results showed that trade openness, infrastructure availability, and market size play significant role in attracting foreign direct investment within a country. The inflow of foreign direct investment has a potential to benefit the investing entity as well as the host government. It also renders economic growth and socioeconomic transformation of the country. The flow of foreign direct investment in Saudi Arabia is affected by several factors including growth rate, GDP, exports and imports. It is the duty of the government to ensure the attractiveness of their country to maintain maximum flow of foreign direct investment, as it promotes sustained long-term economic growth by increased investment in the human capital.
\end{abstract}

Keywords: foreign direct investment, Saudi Arabia, economic growth, economic transformation, capital

\section{Introduction}

Saudi Arabia is among the largest economies in the Middle East and North Africa (MENA) regions. Oil revenues in Saudi Arabia made about 90-95\% of the total earning from export; therefore, economic development of Saudi Arabia positively depends on the oil revenues (Almubarak, 2009). Moreover, oil revenues are helpful to gain approximately $35-40 \%$ of country's GDP. The economic development of Saudi Arabia is pressurized in the form of diversification, liberalization, and reformation due to its heavy dependence on oil revenues (Wright, 2016).

Foreign direct investment (FDI) has been considered as the main vehicle for the movement of international capital. However, the flow of foreign direct investment and capital has occurred in different; and sometimes, in opposite directions. For instance, the flow of foreign direct investment from United States to Western countries is similar to the sizable purchases of United States assets by the national European citizens. This type of interflows in the country cannot be explained through the traditional theory of international movement of capital. Therefore, markets need to provide efficient way of transferring capital for securities, under competitive conditions. The national enterprises within a country are capable of operating at lower costs as compared to the subsidiaries of foreign enterprises. Therefore, the determinants of direct investment need to be in actual deviations apart from the competitive conditions (Chaudhuri \& Mukhopadhyay, 2014).

The superiority of the firms is explained on the basis of product cycle theory because the historical patterns of foreign direct investment cannot be defined through the advantages of superior knowledge. The imperfections in stock markets are neglected, which may result in discrepancies between the expected rate of returns and risks associated with the investment. The foreign direct investment equalizes the rate of return for the companies that are at financial risk (Zhang \& Lei, 2014). The FDI is stimulated to a strong currency area by the exchange risks. However, the overvaluation of dollar as compared to other currencies has provided substantial incentive for the foreign direct investment.

The FDI is represented as any investment in a country that is carried out by some private entities. Moreover, majority of the foreign direct investments are rendered by the multinational companies in the developing countries. It is responsible for narrowing the gap between the targeted investment and locally mobilized savings due to technological advancements. It also narrows the gap between net export earnings, targeted foreign exchange needs, and net foreign aid. The availability of different resources is the driving force behind direct investments in Saudi Arabia because of the new emerged markets and growth potential in various regions. Other factors utilized as driving force for foreign direct investment include; change in market dynamics and 
competition (Alvarez \& Marin, 2013).

The multinational corporations render foreign direct investments by providing resources like; entrepreneurial capabilities, management experience, and technological skills, which are easily learned through various training programs. The FDI helps in the integration of economies at the phase of production in the globalized world economy through various factors including; technology, capital, access to foreign markets, and managerial skills (Badr \& Ayed, 2015). However, the natural resources and assets like research and development are accessible to the foreign direct investments. In terms of FDI, Saudi Arabia possess favorable and unfavorable factors. For instance, poor business policies and increased level of unemployment render unfavorable conditions; whereas, the oil availability has been considered as a contributing factor towards investment.

Saudi Arabia renders similar benefits, incentives, and guarantees to the foreign investors and Saudi Arabian companies. The investors are permitted to remit their funds abroad by $15 \%$ reduction in the taxes for the foreign companies, which render a profit of around 100,000 Saudi riyals (Abdulrahim, 2015). The foreign direct investment is known as a significant tool for development in different countries. It not only results in improvement of capital formation, but it also enhances the balance of payment and creates job opportunities within the host country (Abdulrahim, 2015). According to Rachdi and Saidi (2011), foreign direct investment has stimulated economic growth in the developing countries.

Different policies are focused for the promotion of investment and privatization to achieve the desired reforms and liberalization. In Saudi Arabia, private investment has been encouraged widely. It has led to the introduction of foreign direct investment as a significant aspect to revitalize the country's economy and diversification of its productive base. These services rendered to the manufacturing and other sectors that positively influence the income, production, and employment within a country. This study has highlighted the determinants of foreign direct investment that prevails in Saudi Arabia. The role of market size, returns, and country risk in attracting foreign direct investment, economic integration through international trade, and the wage rates have also been analyzed. The study has aimed to investigate the determinants of foreign direct investment in economic development of Saudi Arabia.

\section{Literature Review}

The FDI prevailing in Saudi Arabia, has been assumed among three forms of investment that include greenfield investment, joint ventures, and investments associated with the offset programs (Almubarak, 2009). Joint ventures developed between Saudi government and the companies were dominant prior to the New Investment Law. The offset program in Saudi Arabia has been associated with its foreign partners. Saudi Arabia tends to focus on the development and diversification of its national economy, which is responsible for the long term economic growth of the country (Abdulrahim, 2015).

The countries, receiving increased inflow of foreign capital, experienced faster economic growth as compared to the countries receiving decreased inflow of foreign direct investment. However, the concept of foreign direct investment and its impact of economy of Saudi Arabia have not been analyzed. The participation of foreign investment firms in Saudi Arabia started in 1960s; but by the year 2000, it increased to 100\% of their investment (Moser et al., 2015). Therefore, it is believed that the foreign direct investment positively affects the country socially, culturally, and economically.

The globalization across the world has increased rapidly due to the technological advancements. It has led to growth of the interdependence among different countries, and the countries seek new markets to cope up with the growing competition. The internal and external factors of different companies have triggered the expansion of new markets. The external factors that are responsible for this expansion include; unsolicited orders, foreign market opportunities, and declining home market of the country. Whereas, the internal factors affecting the expansion of new market are; marketing advantages, risk diversification, economies of scale, and excessive resources (Abdulrahim, 2015).

Saudi Arabia has gained much advantage from the foreign direct investment just like other developing countries. The role of FDI in Saudi's economic growth was analyzed by Ramaday et al. (2007). The results of the study depicted that Saudi Arabia has made significant efforts to attract foreign investors. The foreign direct investment has created employment opportunities and increased GDP in Saudi Arabia. Moreover, the leaders and managers in Saudi Arabia have welcomed the concept of foreign direct investment as a great benefit for the country's economy. The foreign firms greatly affect the behavior of consumers in the host country, when the foreign firms tend to introduce their new products. However, the foreign direct investment has created a new infrastructure and employment opportunities for the citizens of Saudi Arabia. 
The significant factors that attract foreign direct investment in the Arab countries include; trade openness, right infrastructure, and quality of institutions within the country (Abdulrahim, 2015). An important role has been played by the overall economic performance of Saudi Arabia to attract maximum foreign direct investment. The impact of FDI in countries is reflected through different ways of government by which they attract the investors into their country. Therefore, it is believed that foreign direct investment has the ability to exhibits trade sensitivity. The flow of foreign direct investment in Saudi Arabia is significant as it helps in achieving stability, growth, and self-reliance.

\subsection{Influence of Foreign Direct Investment on Country's Economy}

Foreign direct investment is responsible for laying foundations that assist the economic growth and generate domestic savings and foreign currency. It helps in the reduction of commodity prices by improving the quality of national products through the transfer of advanced technology in the developing countries (Johnson, 1972). The FDI has proved to be more conductive for economic development and long run growth, apart from the capital inflows. A study investigated positive association between GDP growth rates, reliability of infrastructure, and flow of foreign direct investments. The regulatory framework of host country serves as a significant predictor of level of foreign direct investment (Neda Abdulaziz, 2009).

FDI also brings foreign management skills and technology, which is adapted by the host country. However, more foreign direct investment is attracted by the countries with growing economies. The flow of FDI increases among the countries interested in providing services or goods to the emerging markets. The investors of foreign direct investment are mainly concerned about the inflexible regulations, political instability, and poor development indicators within the country (Walsh \& Yu, 2010). The emerging markets are observed to possess increased inflation rate, lower development indicators, and poor institutions.

Increase in foreign direct investment is associated with larger markets in the host country, depending on the increased potential demand and decreased economies of scale. However, higher foreign direct investment decreases the openness because the investing companies get benefits from circumventing trade barriers via various production sites (Sbia et al., 2014). Foreign direct investment is attracted by the export orientation, which positively affects the trade within the country. The inflow of foreign direct investment is increased when the currency of host country is weak, which makes the assets of host country cheap relative to the assets within the home country. The main concerns of potential foreign investors are the macro-economy and political stability of the country.

An efficient government system is positively associated with higher economic growth, which attracts maximum foreign direct investment within the country. However, corruption is aided by the poor institutions, which causes reduction in the profit and increase the rate of investment. The investors become sensitive to uncertainty like political uncertainty due to poor institutions as a result of high sunk cost of foreign direct investment.

\subsection{Determinants of Foreign Direct Investment}

The foreign direct investments help to achieve rapid economic growth within developing countries by narrowing the gap between investments and domestic savings and bringing the latest technology from the developed countries. The developing countries are not considered as favorable destinations by foreign investors as compared to the developed countries (Mottaleb \& Kalirajan, 2010). The countries that possess increased GDP growth rates, business friendly environment, and high proportion of international trade are more likely to attract maximum foreign direct investment. The determinants influencing the flow of FDI include:

- Economic environment: The economic development, economic structure, and abundance of natural resources are considered as significant factors for maximum attraction of foreign direct investment.

- Policies of the country: It is believed that the rules, regulations, laws, and other policies of the country significantly affect the foreign direct policy.

- Policies of industrial sector: The policies prevailing in the industrial sector of a country greatly affect the trends of investments in the developing countries.

- Political factor: It plays an important role in political stability of the country as it assists the direction and effect foreign direct investment within a country.

The capital flow within a country has been considered as the key feature of current financial crisis prevailing in the emerging markets. Therefore, the developing countries extensively depend on the FDI as compared to other sources of finance. The level of country's productivity is affected by the macroeconomic environment and maintenance of macroeconomic stability is a great challenge for the developing countries (Iqbal, 2001). The 
factors that determine the foreign direct investments across different countries are employed with different econometric specifications. The foreign capital received by the countries in the form of foreign direct investments is significant for the economic growth and development of the country (Flora \& Agrawal, 2014).

\section{Discussion}

The study has highlighted different determinants of foreign direct investment. The stability of exchange rates, dealing with official bodies, obtaining investment licenses, custom exemptions, and grants to tax investors significantly depend on the foreign direct investments. The global flow of foreign direct investment has risen by 16\% to USD 1,524 billion in 2011 from USD 1,309 billion in 2010 (Flora \& Agrawal, 2014). The FDI benefits the recipient country economically by providing it foreign exchange, technology, and capital. It increases the competition between different countries and helps to gain access to the foreign markets. The two approaches associated with the investigation of foreign direct investment and economic growth includes; time series approach and production function approach (Harms \& Ursprung, 2002). Moreover, economical and positive role is played by the trade openness, institutions, and GDP size on the inflow of foreign direct investments. On the contrary, a study revealed that strong association between inflow of foreign direct investment and economic growth does not indicate that increased amount of investment would result in a rapid growth of the country's economy (Choe, 2003).

A study conducted by Pradhan (2009) revealed 2 way link between economic growth and foreign direct investment. For instance, increased inflow of FDI stimulates economic growth within the host country, which eventually attracts more flow of foreign direct investment. A positive correlation is observed between economic growth of the country and flow of foreign direct investment. A country undergoing consistent, but steady positive economic growth has been proved as an attractive destination for the investors as compared to the countries experiencing moderate to slow growing economy. Although, the economic growth and foreign direct investment are positively correlated, but the host country needs to attain a specific level of development, which helps to achieve high levels of productivity (Flora \& Agrawal, 2014). Rogmans and Ebbers (2013) tested the determinants of foreign direct investment and revealed that the flow of FDI is negatively affected by the energy endowments. The oil prices, openness to trade, and GDP are positively associated with the inflow of foreign direct investment. However, the countries, which possess large amounts of gas and oil, have certain institutions and policies that inhibit the flow of foreign direct investment within the country.

According to Lui et al. (2006), there is a positive factor for the economic growth rate within a country, which suggested that increased rate of economic growth tends to attract more FDI. Another study revealed the association between economic growth and foreign direct investment, and stated that developing countries are capable of attracting more investments as they possess investment friendly policies and high rate of economic growth (Mottaleb, 2007). The evaluation of correlation between economic growth and foreign direct investment together with the role of financial sector revealed that there are strong, positive, and significant effects of investments on economic growth of the developing countries. Roy and Mandal (2012) conducted a study to investigate the impact of foreign direct investment on the economic growth of countries by utilizing the co-integration approach between the years 1990 and 2011. The results revealed that there is a positive correlation between GDP and foreign direct investments.

Carkovi and Levine (2002) investigated the association between economic growth and flow of foreign direct investment within 72 countries. The results revealed that there is no independent impact of foreign direct investment on the economic growth of developing and developed countries. Moreover, Duasa (2007) stated that foreign direct investment does not contribute towards economic stability of the country. However, the correlation between economic growth and foreign direct investment may vary across the economies of different countries on the basis of time considered for conducting the analysis. The present study has contributed new information to the international business literature, particularly focusing on the association between foreign direct investment and economic growth.

The economic development and growth are induced as a result of increased foreign direct investments. However, if economic growth tends to attract foreign direct investment, then it is necessary to implement various policies to attract maximum investments. Amri (2016) investigated bi-directional linkages between the foreign direct investment, energy consumption, and gross domestic product per capita in the developed as well as developing countries. The foreign direct investment was improved by $0.185 \%$ with an increase in $1 \%$ rate of the renewable energy. Eventually, increase in FDI is responsible for enhancement in renewable energy by $0.292 \%$ (Amri, 2016). Another study revealed that a non-linear relationship exists between the foreign direct investment and measure of market income and size. 
The study has yielded various insights about attracting foreign direct investment within a country. The FDI strongly depends on the country's macroeconomic stability, institutional quality, and level of development. The determinants of foreign direct investment are observed to be different among the emerging and advanced economies. More services regarding foreign direct investment are attracted on the basis of independent judiciary and effective infrastructure within the country. The significant gravity variables associated with foreign direct investment are parent-country per capital GDP, cultural factors, trade agreements, and labor endowments.

The foreign investments are considered as a significant part of country's economic growth. The positive effects of FDI on labor, product, capital market, and technology are responsible for its attraction within the developing countries. FDI is considered as a rich source to generate income through technological advancement, management skills, market proficiency, governance measures, and inflow of capital. It is necessary to fabricate favorable policies to attain economic growth through maximum flow of foreign direct investments, especially in the transition phase. In order to encourage different potential sources of economic development, efforts are needed to enhance and stimulate the foreign direct investments.

\section{Acknowledgments}

The author is very thankful to all the associated personnel in any reference that contributed in/for the purpose of this research. Further, this research holds no conflict of interest and is not funded through any source.

\section{References}

Abdulrahim, J. (2015). The impact of foreign direct investment on Saudi Arabia.

Almubarak, N. A. (2009). Determinants of foreign direct investment in the Kingdom of Saudi Arabia: A cross country analysis. Georgetown University.

Álvarez, I., \& Marin, R. (2013). FDI and technology as levering factors of competitiveness in developing $\begin{array}{llll}\text { countries. Journal of International } & \text { Management, } & 19(3), & \text { 232-246. }\end{array}$ https://doi.org/10.1016/j.intman.2013.02.005

Badr, O. M., \& Ayed, T. L. (2015). The Mediator Role of FDI in North Africa: Case of Egypt. Journal of Advanced Management Science, 3(1). https://doi.org/10.12720/joams.3.1.1-7

Carkovic, M. V., \& Levine, R. (2002). Does foreign direct investment accelerate economic growth? https://doi.org/10.2139/ssrn.314924

Chaudhuri, S., \& Mukhopadhyay, U. (2014). Foreign direct investment in developing countries. Dordrecht: Springer. https://doi.org/10.1007/978-81-322-1898-2

Choe, J. I. (2003). Do foreign direct investment and gross domestic investment promote economic growth? Review of Development Economics, 7(1), 44-57. https://doi.org/10.1111/1467-9361.00174

Duasa, J. (2007). Malaysian foreign direct investment and growth: does stability matter?. Journal of Economic Cooperation Among Islamic Countries, 28(2).

Flora, P., \& Agrawal, G. (2014). Foreign direct investment (FDI) and economic growth relationship among highest FDI recipient Asian economies: A panel data analysis. International Business Management, 8(2), 126-132.

Grubaugh, S. G. (2013). Determinants of Inward Foreign Direct Investment: A Dynamic Panel Study. International Journal of Economics and Finance, 5(12), 104. https://doi.org/10.5539/ijef.v5n12p104

Harms, P., \& Ursprung, H. W. (2002). Do civil and political repression really boost foreign direct investments?. Economic Inquiry, 40(4), 651-663. https://doi.org/10.1093/ei/40.4.651

Iqbal, Z. (Ed.). (2001). Macroeconomic Issues and Policies in the Middle East and North Africa. Washington, DC: International Monetary Fund.

Johnson, H. (1972). The Efficiency and Welfare Implementation of Corporation in International Investment. Edited by John Du Books.

Liu, L. G., Chow, K., \& Li, U. (2006). Determinants of foreign direct investment in East Asia: Did China crowd out FDI from her developing East Asian neighbours (No. 0617).

Moser, S., Swain, M., \& Alkhabbaz, M. H. (2015). King Abdullah Economic City: Engineering Saudi Arabia's post-oil future. Cities, 45, 71-80. https://doi.org/10.1016/j.cities.2015.03.001

Mottaleb, K. A. (2007). Determinants of foreign direct investment and its impact on economic growth in developing countries. 
Mottaleb, K. A., \& Kalirajan, K. (2010). Determinants of foreign direct investment in developing countries a comparative analysis. Margin: The Journal of Applied Economic Research, 4(4), 369-404. https://doi.org/10.1177/097380101000400401

Neda Abdulaziz, M.P.P. (2009). Determinants of foreign direct investment in the Kingdom of Saudi Arabia: A cross country analysis.

Rachdi, H., \& Saidi, H. (2011). The impact of foreign direct investment and portfolio investment on economic growth in developing and developed economies. Interdisciplinary Journal of Research in Business, 1(6), 10-17.

Ramady, M. A., \& Saee, J. (2007). Foreign direct investment: A strategic move toward sustainable free enterprise and economic development in Saudi Arabia. Thunderbird International Business Review, 49(1), 37-56. https://doi.org/10.1002/tie.20130

Rogmans, T., \& Ebbers, H. (2013). The determinants of foreign direct investment in the Middle East North Africa region. International Journal of Emerging Markets, 8(3), 240-257. https://doi.org/10.1108/17468801311330310

Sbia, R., Shahbaz, M., \& Hamdi, H. (2014). A contribution of foreign direct investment, clean energy, trade openness, carbon emissions and economic growth to energy demand in UAE. Economic Modelling, 36, 191-197. https://doi.org/10.1016/j.econmod.2013.09.047

Walsh, J. P., \& Yu, J. (2010). Determinants of foreign direct investment: A sectoral and institutional approach. https://doi.org/10.5089/9781455202218.001

Wright Jr, J. W. (Ed.). (2016). Business and economic development in Saudi Arabia. Springer.

Zhang, J., \& Lei, H. O. U. (2014). Financial structure, productivity, and risk of foreign direct investment. Journal of Comparative Economics, 42(3), 652-669. https://doi.org/10.1016/j.jce.2013.06.002

\section{Copyrights}

Copyright for this article is retained by the author(s), with first publication rights granted to the journal.

This is an open-access article distributed under the terms and conditions of the Creative Commons Attribution license (http://creativecommons.org/licenses/by/4.0/). 